\title{
Impact of supplementation with beetroot juice (Beta vulgaris L) on levels of malondialdehyde and antioxidant status in athletes
}

\author{
Fajar Apollo Sinaga*, Rika Nailuvar Sinaga \\ Department of Sports Sciences, Faculty of Sports Sciences, Universitas Negeri Medan \\ Medan, North Sumatra, Indonesia \\ Jl. Pancing, Psr V, Kota Medan, North Sumatera, Indonesia
}

Submitted: 27-04-2019

Reviewed: 05-05-2020

Accepted: 06-11-2020

\begin{abstract}
Strenuous physical activity can increase lipid peroxidation, which is characterized by increased levels of malondialdehyde (MDA) and decreased levels of antioxidants. It can drop the athlete's performance and health. It is possible to avoid or reduce lipid peroxidation through supplementation with antioxidants. Beetroot (Beta vulgaris L) produces different forms of natural antioxidants; however, its effectiveness still needs to be investigated. This research aimed to determine the impact of beetroot juice on the malondialdehyde concentration and antioxidant status during strenuous physical activity. The research used experimental (pre-test-post-test) using a control group. The researchers divided a total of 30 students who met the criteria into two groups (Experiment; $\mathrm{n}=15$; control; $\mathrm{n}=15$ ). The experimental group drank $250 \mathrm{~mL}$ of the juice 1 hour before training for four weeks. After the strenuous physical activity was carried out with a beep test, the researchers also checked the concentrations of MDA, TAC, and $\mathrm{VO}_{2}$ max. The findings indicated a decrease in MDA concentration and an increase in $\mathrm{TAC}$ and $\mathrm{VO}_{2} \max$ to the training group that received $250 \mathrm{ml}$ beet juice $(\mathrm{p}<0.05)$. The research concluded that beetroot juice administration during exercise could reduce malondialdehyde concentration and increase total antioxidant capacity and $\mathrm{VO}_{2}$ max in athletes.
\end{abstract}

Keywords: beetroot juice, malondialdehyde, antioxidants, strenuous physical activity, exercise

\footnotetext{
*Corresponding author:

Fajar Apollo Sinaga

Department of Sports Sciences, Faculty of Sports Sciences, Universitas Negeri Medan

Jl. Pancing Psr V Medan, North Sumatra, Indonesia

Email:sinaga_fajar@yahoo.com
} 


\section{INTRODUCTION}

Exercise causes various physiological changes of varying magnitude and direction, depending on the exercise characteristics and the subject's health and training level. Oxygen flux can be increased by 100-200 times during strenuous exercise because of an improvement in metabolism in the body (Joyner and Casey, 2015). Enhanced use of oxygen predominantly by muscle contraction, increasing mitochondrial electron leakage that will become reactive oxygen compounds (Nemes et al., 2018). Generally, 2-5\% of the oxygen in the body used in metabolic processes can become superoxide ions so that free radical development increases during intense physical activity (Simioni et al., 2018). Oxidative stress will occur when free revolutionary development exceeds antioxidants for cellular protection, where physical activity is one of the contributing factors (Kawamura and Muraoka 2018; Marius-Daniel et al., 2010). In oxidative stress conditions, free radicals can cause lipid peroxidation to the cell membrane resulting in cell damage (Ayala et al., 2014; Evans 2000). During strenuous physical exercise or high-intensity resistance training, malondialdehide will form as a result of lipid peroxidation (Bao et al., 2016; Liu et al., 2019; Xu et al., 2017). The increase in MDA concentration during strenuous physical exercise has been used as an indicator measuring the number of free radicals formed (Liu et al., 2019).

The findings show that it will cause a decrease in endogenous antioxidant concentration (Thirumalai et al., 2011). Meanwhile, recorded that volleyball athletes running a distance of 20 meters could cause lipid peroxidation characterized by an increased concentration of malondialdehyde and decreased antioxidant catalase concentration glutathione peroxidase.

Due to maximum and sub-maximum physical activity, decreased antioxidant levels and increased CK and lipid peroxidation can be prevented by improving diet, primarily by increasing antioxidants' content (Kim et al., 2005; Pingitore et al., 2015; Simioni et al., 2018). Accordingly, (Gomez-Cabrera et al., 2008) said that the oxidative damage that occurs after strenuous physical activity is preventable by consuming high antioxidant content. Vegetables and fruits with antioxidant-rich are more effective than single antioxidants such as vitamin $\mathrm{E}$. The components and interactions of antioxidant-rich vegetables and fruits may play a positive role.

Beetroot (Beta vulgaris L) contains various types of natural antioxidants. One of them is betalain as a substance with healthy antioxidants, which can be an effective antidote to free radicals (Clifford et al. 2015). Other compounds that act as powerful antioxidants in beetroot include betaine (Liliana and Oana-Viorela, 2020; Zhao et al., 2018), phenolic acids, vitamin C, carotenoids, triterpenes, coumarins, and flavonoids. The beetroot's flavonoid compounds include tiliroside, rhamnetin, kaempfero, astragalin, rhamnocitrin (Liliana and Oana-Viorela, 2020; Mirmiran et al., 2020), cochliophilin, betavulgarin, betagarin, and dihydroisorhamnetin (Kujala et al., 2002). Phenolic acid compounds include N-trans-feruloyltyramine, N-trans-feruloylhomovanillylamine (Kujala et al., 2002), caffeic acid, gallic acid, ferulic acid, chlorogenic acid, quercetin, p-coumaric acid, kampferol, syringic acid, ellagic acid, myricetin, ellagic acid and vanillic acid (Chhikara et al., 2019; Koubaier et al., 2014). Several studies have reported that giving beets in the form of juice can have anti-anaemia effects (Putri and Tjiptaningrum, 2016), blood pressure and lipid-lowering (Hobbs et al., 2012), anti- inflammation (Clifford et al., 2015), anticancer (Lechner and Stoner, 2019), antioxidative (Kozłowska et al., 2020), anti-diabetic (Sanjeev et al., 2020).

Researchers are interested in the speciality of beetroot with different types of antioxidants. They need to analyze the antioxidant impact of supplementation with beetroot juice (BRJ) on malondialdehyde and antioxidant status in maximal physical activity.

\section{MATERIALS AND METHOD Materials}

Beetroot (Beta vulgaris L) obtained from the Medan MMTC market, 1\% EDTA solution, Aquadest, MDA Kit and TAC purchased from Shanghai, China. 
Tool

Spectrophotometer (Shimadzu), glassware, spuit, juicer, cones, multistage fitness test audio, compact disk, sheet for performance recording

\section{Methods \\ Participants}

This research used 30 sports science students who were called athletes. The research criteria were male, aged 20-22 years, had an excellent VO2max level, were not smokers, and had an acceptable Body Mass Index (BMI). Two weeks before and during the study, vitamins and antioxidants were not used, preparing it for the subject. Then obtaining Research and ethical permission from the Faculty of Medicine Ethical Commission, University of North Sumatra No:277 / KEP / USU/2020

\section{Research implementation}

The athletes led to haematological examination to measure MDA and TAC levels after strenuous physical activity by performing a beep test (pretest). Furthermore, dividing them into two groups: the experimental group (given beet juice, $\mathrm{n}=15$ ) and the control (as a placebo, $\mathrm{n}=$ 15). During four weeks, the athletes consumed $250 \mathrm{~mL}$ of beetroot juice (BRJ) 1 hour before training. Then, they performed strenuous physical activity after one month by doing a beep test and continuing to another haematology examination to measure the MDA and TAC levels (post-test).

\section{MDA and TAC determination}

Researchers drew blood $(5 \mathrm{~mL})$ before and after treatment to test for MDA and TAC and brought it to the laboratory. Blood is taken from the antecubital vein and put into a test tube containing an anticoagulant agent. To analyze the MDA and TAC, researchers used ELISA (enzyme-linked immunosorbent assay) colourimetric approach and followed the procedures defined in each MDA and TAC kit.

\section{Data Analysis}

Researchers reported all study data as means and standard deviation. The research data were analyzed using IBM statistics for windows 25 . The research data were analyzed using IBM statistics for windows 25 . Statistical analysis using a paired t-test used to determine the average difference between pretest and post-test data. Statistical analysis using independent samples t-test used to determine the difference between the experimental and control groups. The statistical significance set at $P<0.05$ before analyses

\section{RESULT AND DISCUSSION \\ Impact of beetroot juice (Beta vulgaris $\mathrm{L}$ ) on malondialdehyde levels}

The pre-test malondialdehyde (MDA) amount in the treatment group was $1.98 \pm 0.37$ $\mathrm{nmol} / \mathrm{ml}$ based on the research results, while the control group was $2.11 \pm 0.24 \mathrm{nmol} / \mathrm{mL}$. The results of statistical tests showed that there was no difference in malondialdehyde levels between the experimental group and the control group. The MDA measurement results were $5.75 \pm 0.51$ $\mathrm{nmol} / \mathrm{ml}$ in the post-test treatment group, while the control group received MDA levels of $10.69 \pm$ $0.97 \mathrm{nmol} / \mathrm{mL}$. Differences in levels of pre-test-post-test MDA treatment groups and control groups $(\mathrm{p}=0,000)$ were obtained from the results of the analysis using the paired sample t-test. The independent sample t-test statistical test results found a substantial difference in post-test MDA levels between the treatment and control groups $(\mathrm{p}=0,000)$ 
In the analysis, MDA levels in the group that did not contain beet juice was higher than in the group containing beet juice. High MDA levels in the group that did not contain beet juice indicated that free radicals produced during strenuous physical activity which oxidized the cell membranes (Figure 1).

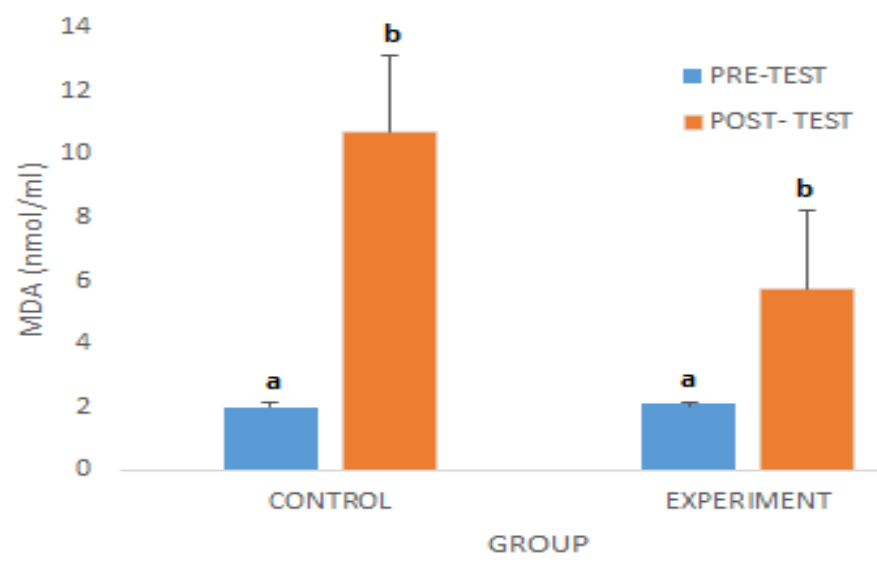

Figure 1. Impact of supplementation with BRJ on the level of malondialdehyde. In each group, the data is mean \pm SD for $n=15$. Different letters suggest a significant difference between paired t-test samples at $\mathrm{p}<0.05$

Several reports support the findings of research results, including reporting that acute aerobic physical activity contributes to oxidative stress, especially when exercising at high intensity. Two mechanisms that cause oxidative stress in high-intensity aerobic exercise are increased prooxidants through the effect of increasing oxygen consumption 10 to 15 times compared to rest and relatively insufficient antioxidants compared to pro-oxidants (Alessio et al., 2000). Meanwhile, according to ( $\mathrm{Ji}, 1999)$, oxygen consumption throughout the body increases to 20 times during maximum physical activity, while oxygen consumption in muscle fibers is estimated to increase to 100 times. Free radicals induce lipid peroxidation of cell membranes under oxidative stress conditions and destroy the organization of cell membranes (Evans, 2000). Increased levels of MDA triggered by physical activity have been reported by many researchers, including (Moflehi et al., 2012) who examined the effect of aerobic exercise with different intensities on increasing levels of MDA and $\mathrm{CK}$ in people who are not athletes. This study's findings show that the higher the exercise intensity, the greater the amount of MDA. In this study, aerobic exercise for 20 minutes with an intensity of $80 \%$ can increase MDA levels compared to controls $(9.09 \pm 2.08$ Vs $2.69 \pm$ $1.32 \mu \mathrm{mol} / \mathrm{L})$. Meanwhile, research conducted reported that volleyball athletes who carried out a 20 meter shuttel run test with $\mathrm{VO}_{2}$ max levels of $41.78 \pm 4.91 \mathrm{~mL} / \mathrm{kg} / \mathrm{min}$ turned out to increase MDA levels from $1.41 \pm 0.30 \mathrm{nmol} / \mathrm{ml}$ to $2.06 \pm 0.08 \mathrm{nmol} / \mathrm{L}$, while non-athletes with $\mathrm{VO}_{2} \mathrm{max}$ levels of $26.91 \pm 3.67 \mathrm{ml} / \mathrm{kg} / \mathrm{min}$, MDA levels increased from $0.94 \pm 0.24 \mathrm{~mL} / \mathrm{kg} / \mathrm{min}$ to $1.10 \pm 0.21$ $\mathrm{mL} / \mathrm{kg} / \mathrm{min}$. In this research, giving beetroot juice during exercise can decrease MDA levels when athletes perform full physical activity compared to MDA levels in the control group. The decrease in MDA levels is due to the antioxidant content found in beets (Beta vulgaris L). It is known, beets contain antioxidants including phenolic compounds, flavonoids, vitamin $\mathrm{C}$, carotenoids and betalains. Betalains contained in beets are betacyanin and betaxhantine (Georgiev et al., 2010; Kujala et al., 2002; Ninfali and Angelino, 2013). Some in vitro research findings indicate that betalaine pigments can protect cellular components from oxidative injury (Kanner et al. 2001; Tesoriere et al. 2008). In the study by Kanner et al, for example , two betalain metabolites (betanine and betanidine) showed a reduction in linoleic damage caused by cytochrome $\mathrm{C}$ oxidase and metmyoglobin-activated $\mathrm{H}_{2} \mathrm{O}_{2}$ and free iron (AA-Fe) mediated lipid membrane oxidation. The

Pharmaciana Vol. 10, No.3, Nov 2020, Page. 305 - 314 
researchers also report that betanine, the most abundant betalaine $(300-600 \mathrm{mg} / \mathrm{kg}$ ) found in beets, is the most powerful lipid peroxidation inhibitor. Betanin's high antioxidant activity is thought to derive from its remarkable capacity to donate electrons and its power to disperse very reactive radicals that attack cell membranes (Kanner et al. 2001). Also, beets contain $\mathrm{NO}_{3}$ compounds (nitrates) which have been shown to suppress the formation of free radicals such as superoxide and hydrogen peroxide (Lundberg et al., 2011; Winkler et al., 2005).

\section{Impact of Beet Juice (Beta vulgaris L) on Total Antioxidant Capacity (TAC)}

The research results obtained pretest TAC levels in the treatment group were $1.53 \pm 0.06$ $\mathrm{U} / \mathrm{ml}$, while the control group was $1.50 \pm 0.13 \mathrm{U} / \mathrm{mL}$. The results of statistical tests showed that there was no difference in TAC levels between the experimental group and the control group. The measurement of the TAC post-test of the treatment group was $3.39 \pm 0.08 \mathrm{U} / \mathrm{mL}$, while the control group obtained TAC levels of $2.46 \pm 0.11 \mathrm{U} / \mathrm{mL}$. Statistical tests using the t-test showed differences in pre-test-post-test TAC levels in the experimental group or the control group $(\mathrm{p}=$ 0.000). The results of statistical tests using the independent samples t-test showed a significant difference in post-test TAC levels between the treatment and control groups $(p=0,000)$.

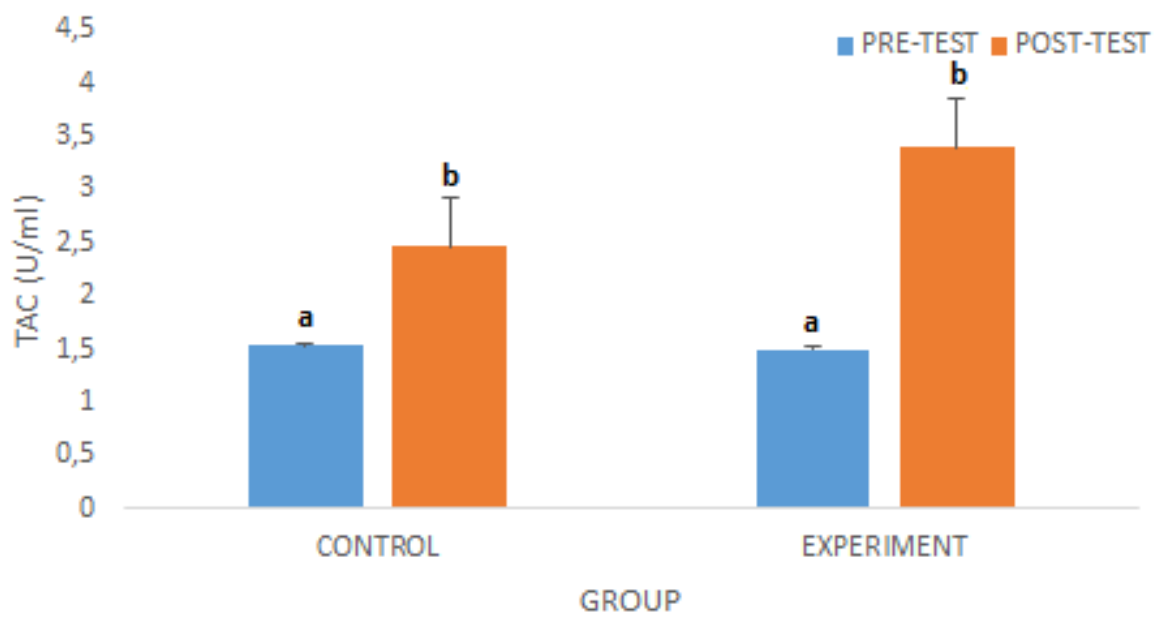

Figure 2. Impact of supplementation with BRJ on the level of total antioxidant capacity. In each group, the data is mean \pm SD for $n=15$. Different letters suggest a significant difference between paired t-test samples at $p<0.05$

Giving beetroot juice in Figure 2 shows that TAC levels will increase when compared to the control group. Increased TAC levels due to beetroot juice are due to the antioxidant content of beets such as betaine, phenol compounds, flavonoids, vitamin $\mathrm{C}$, carotenoin and betalains. Betalains contained in beets are betacyanin and betaxhantine (Georgiev et al., 2010; Kujala et al., 2002; Ninfali and Angelino, 2013). Research conducted by Kujawska et al., on the antioxidant and anti-inflammatory effects of beetroot juice on oxidative stress induced by $\mathrm{N}$-nitrosodiethylamine (NDEA) and carbon tetrachloride $\left(\mathrm{CCl}_{4}\right)$ administration confirms the findings of this report. In his research, giving beetroot juice to mice given NDEA and $\mathrm{CCl} 4$ can reduce the process of lipid peroxidation in the liver, which is indicated by a 38\% reduction in TBARS levels. In his research, pretreatment with juice induced a partial recovery of $35 \%$ and $66 \%$, respectively, of glutathione peroxidase and glutathione reductase activity. Superoxide dismutase activity was approximately 3fold increased in juice pretreated animals. Both xenobiotics caused an increase in carbonyl plasma protein, which was decreased by $30 \%$ in rats pretreated with juice and then injected with NDEA (Kujawska et al., 2009). Analysis performed by Lu et al. (2009) has also confirmed the findings of 
the study. In the study, they investigated the radioprotective role of beetroot betalate in lightirradiated rats (60) Co gamma (6.0 Gy, at a dose of $1.5 \mathrm{~Gy} \min (-1))$. They randomly grouped the rats into five, namely the control group and four experimental groups, which obtained one of four beetroot betalain $(0,5,20$ and $80 \mathrm{mg} / \mathrm{kg}$ for 30 days) concentrations. Gamma Co (ray) 60 was subsequently exposed to the four groups of experimental mice and betalains were administered from beets for the next three days. The study results showed that administration of betalains from beetroots was radioprotective in mice irradiated by (60) Co in vivo. The underlying mechanism was thought to be mediated by betalain's antioxidant activity from beetroots and immune system modulation.

\section{Impact of giving beetroot juice (Beta vulgaris $\mathrm{L}$ ) on $\mathrm{VO}_{2} \mathrm{max}$}

The pretest $\mathrm{VO}_{2}$ max levels in the treatment group were $47.59 \pm 0.44 \mathrm{~mL} / \mathrm{kg} / \mathrm{min}$ based on the findings, while the control group was $47.75 \pm 0.53 \mathrm{~mL} / \mathrm{kg} / \mathrm{min}$. The study's findings using separate t-test samples showed no differences between the treatment group and the control group in pretest $\mathrm{VO}_{2}$ max levels. The results of the post-test measurement of $\mathrm{VO}_{2}$ max levels for the treatment group were $52.95 \pm 0.57 \mathrm{ml} / \mathrm{kg} / \mathrm{min}$, while the control group obtained $\mathrm{VO}_{2}$ max levels of $50.53 \pm 0.87 \mathrm{~mL} / \mathrm{kg} / \mathrm{min}$. The analysis results using the Paired Sample t-test showed an increase in $\mathrm{VO}_{2} \mathrm{max}$ levels in the pre-test-post-test treatment group or the control group $(\mathrm{p}=0.000)$. The statistical test results with independent samples t-test showed a substantial difference between the treatment and control groups in post-test $\mathrm{VO}_{2}$ max levels $(\mathrm{p}=0,000)$.

Figure 3 shows that beetroots juice administration during exercise can increase $\mathrm{VO}_{2} \max$ compared to the control group. This increase in $\mathrm{VO}_{2} \max$ occurs due to nitrate content and antioxidant content possessed by beetroots. The results showed $500 \mathrm{ml}$ of beetroot juice containing nitrates as much as 5.1-6.2 mmol (Bailey et al., 2009; Lansley et al., 2011). Beet tubers have been shown to affect pulmonary oxygen uptake $\left(\mathrm{VO}_{2}\right)$. The results of the study on the consumption of inorganic nitrate $(5.1 \mathrm{mmol}$ nitrate/day) in the form of $500 \mathrm{ml}$ beet juice for six days in 7 adult men (19-38 years), can reduce lung oxygen uptake $\left(\mathrm{VO}_{2}\right)$ at exercise intensity so that it can delay fatigue time (Bailey et al., 2010) .

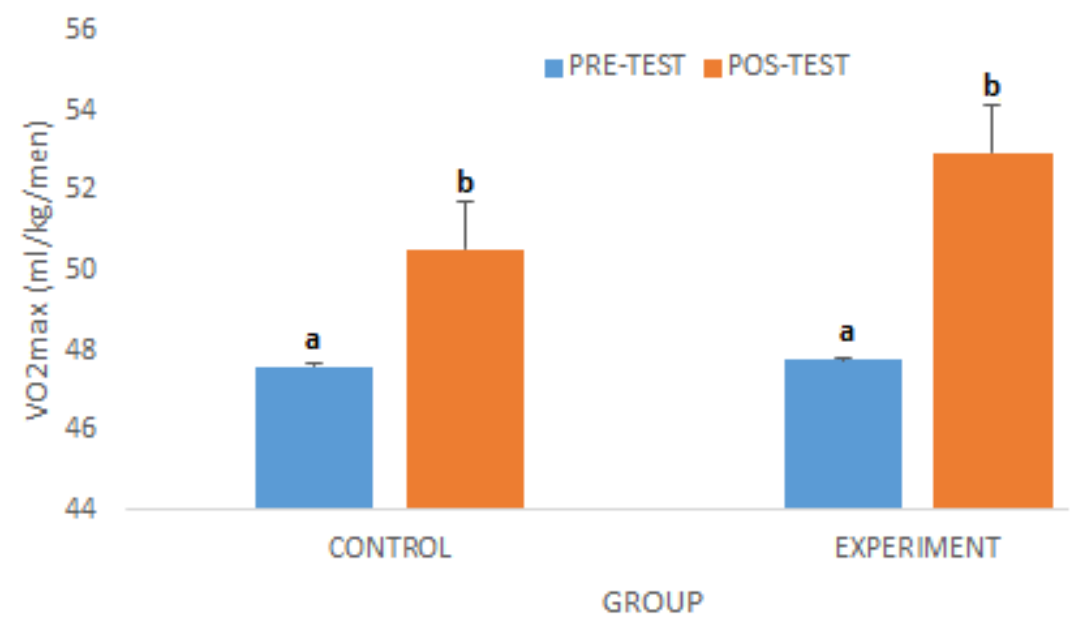

Figure 3. Impact of supplementation with $\mathrm{BRJ}$ on $\mathrm{VO}_{2}$ max. In each group, the data is mean $\pm S D$ for $n=15$. Different letters suggest a significant difference between paired t-test samples at $p<0.05$

The mechanism of action of nitrate $\left(\mathrm{NO}_{3}{ }^{-}\right)$to improve athlete's performance is as follows: Nitrate by bacteria in saliva will be reduced to nitrite $\left(\mathrm{NO}_{2}{ }^{-}\right)$. Furthermore, in the stomach nitrite will be reduced to nitric oxide (NO) (Lundberg et al., 2011; Shiva et al., 2007). Nitric oxide is an 
important signaling molecule with a central role in many physiological processes that can influence sports performance, such as blood flow regulation of tissues, muscle contraction, mitochondrial biogenesis, and absorption of muscle glucose (Stamler and Meissner, 2001). Moreover, improved blood flow from the synthesis of nitric oxide will improve tissue processes recovery (Bloomer, 2010).

\section{CONCLUSION}

The research concluded that beetroots juice administration during exercise could decrease MDA levels and increase TAC and $\mathrm{VO}_{2}$ max levels of the athlete.

\section{ACKNOWLEDGMENT}

The authors thank the Physiology Laboratory at Universitas Negeri Medan for their invaluable support for this research.

\section{REFERENCES}

Alessio, H. M., Hagerman, A. E., Fulkerson, B. K., Ambrose, J., Rice, R. E., \& Wiley, R. L. (2000). Generation of reactive oxygen species after exhaustive aerobic and isometric exercise. Medicine and Science in Sports and Exercise. https://doi.org/10.1097/00005768-20000900000008

Ayala, A., Muñoz, M. F., \& Argüelles, S. (2014). Lipid peroxidation: Production, metabolism, and signaling mechanisms of malondialdehyde and 4-hydroxy-2-nonenal. Oxidative Medicine and Cellular Longevity. https://doi.org/10.1155/2014/360438

Bailey, S. J., Fulford, J., Vanhatalo, A., Winyard, P. G., Blackwell, J. R., DiMenna, F. J., ... Jones, A. M. (2010). Dietary nitrate supplementation enhances muscle contractile efficiency during knee-extensor exercise in humans. Journal of Applied Physiology, 109(1), 135-148.

Bailey, S. J., Winyard, P., Vanhatalo, A., Blackwell, J. R., DiMenna, F. J., Wilkerson, D. P., ... Jones, A. M. (2009). Dietary nitrate supplementation reduces the O2 cost of low-intensity exercise and enhances tolerance to high-intensity exercise in humans. Journal of Applied Physiology. https://doi.org/10.1152/japplphysiol.00722.2009

Bao, L., Cai, X., Wang, J., Zhang, Y., Sun, B., \& Li, Y. (2016). Anti-fatigue effects of small molecule oligopeptides isolated from panax ginseng C. A. meyer in mice. Nutrients. https://doi.org/10.3390/nu8120807

Bloomer, R. J. (2010). Nitric oxide supplements for sports. Strength and Conditioning Journal. https://doi.org/10.1519/SSC.0b013e3181bdaf89

Chhikara, N., Kushwaha, K., Sharma, P., Gat, Y., \& Panghal, A. (2019). Bioactive compounds of beetroot and utilization in food processing industry: A critical review. Food Chemistry. https://doi.org/10.1016/j.foodchem.2018.08.022

Clifford, T., Howatson, G., West, D. J., \& Stevenson, E. J. (2015). The potential benefits of red beetroot supplementation in health and disease. Nutrients. https://doi.org/10.3390/nu7042801

Evans, W. J. (2000). Vitamin E, vitamin C, and exercise. In American Journal of Clinical Nutrition. https://doi.org/10.1093/ajcn/72.2.647s

Georgiev, V. G., Weber, J., Kneschke, E. M., Denev, P. N., Bley, T., \& Pavlov, A. I. (2010). Antioxidant activity and phenolic content of betalain extracts from intact plants and hairy root cultures of the red beetroot Beta vulgaris cv. Detroit Dark Red. Plant Foods for Human Nutrition. https://doi.org/10.1007/s11130-010-0156-6

Gomez-Cabrera, M. C., Domenech, E., \& Viña, J. (2008). Moderate exercise is an antioxidant: Upregulation of antioxidant genes by training. Free Radical Biology and Medicine. https://doi.org/10.1016/j.freeradbiomed.2007.02.001

Hobbs, D. A., Kaffa, N., George, T. W., Methven, L., \& Lovegrove, J. A. (2012). Blood pressurelowering effects of beetroot juice and novel beetroot-enriched bread products in normotensive male subjects. British Journal of Nutrition. https://doi.org/10.1017/S0007114512000190 
Ji, L. L. (1999). Antioxidants and oxidative stress in exercise. In Proceedings of the Society for Experimental Biology and Medicine. https://doi.org/10.1046/j.1525-1373.1999.d01-145.x

Joyner, M. J., \& Casey, D. P. (2015). Regulation of increased blood flow (Hyperemia) to muscles during exercise: A hierarchy of competing physiological needs. Physiological Reviews. https://doi.org/10.1152/physrev.00035.2013

Kanner, J., Harel, S., \& Granit, R. (2001). Betalains - A new class of dietary cationized antioxidants. Journal of Agricultural and Food Chemistry. https://doi.org/10.1021/jf010456f

Kawamura, T., \& Muraoka, I. (2018). Exercise-induced oxidative stress and the effects of antioxidant intake from a physiological viewpoint. Antioxidants. https://doi.org/10.3390/antiox7090119

Kim, S. H., Park, K. S., Chang, M. J., \& Sung, J. H. (2005). Effects of Panax ginseng extract on exercise-induced oxidative stress. Journal of Sports Medicine and Physical Fitness.

Koubaier, H. B. H., Snoussi, A., Essaidi, I., Chaabouni, M. M., Thonart, P., \& Bouzouita, N. (2014). Betalain and phenolic compositions, antioxidant activity of Tunisian red beet (Beta vulgaris L. conditiva) roots and stems extracts. International Journal of Food Properties. https://doi.org/10.1080/10942912.2013.772196

Kozłowska, L., Mizera, O., Gromadzińska, J., Janasik, B., Mikołajewska, K., Mróz, A., \& Wąsowicz, W. (2020). Changes in oxidative stress, inflammation, and muscle damage markers following diet and beetroot juice supplementation in elite fencers. Antioxidants. https://doi.org/10.3390/antiox9070571

Kujala, T. S., Vienola, M. S., Klika, K. D., Loponen, J. M., \& Pihlaja, K. (2002). Betalain and phenolic compositions of four beetroot (Beta vulgaris) cultivars. European Food Research and Technology. https://doi.org/10.1007/s00217-001-0478-6

Kujawska, M., Ignatowicz, E., Murias, M., Ewertowska, M., Mikołajczyk, K., \& Jodynis-Liebert, J. (2009). Protective effect of red beetroot against carbon tetrachloride- and Nnitrosodiethylamine-induced oxidative stress in rats. Journal of Agricultural and Food Chemistry. https://doi.org/10.1021/jf803315d

Lansley, K. E., Winyard, P. G., Bailey, S. J., Vanhatalo, A., Wilkerson, D. P., Blackwell, J. R., ... Jones, A. M. (2011). Acute dietary nitrate supplementation improves cycling time trial performance. Medicine and Science in Sports and Exercise. https://doi.org/10.1249/MSS.0b013e31821597b4

Lechner, J. F., \& Stoner, G. D. (2019). Red beetroot and betalains as cancer chemopreventative agents. Molecules. https://doi.org/10.3390/molecules24081602

Liliana, C., \& Oana-Viorela, N. (2020). Red Beetroot: Composition and Health Effects - A Review. Journal of Nutritional Medicine and Diet Care, 5(2). https://doi.org/10.23937/25723278.1510043

Liu, R., Wu, L., Du, Q., Ren, J. W., Chen, Q. H., Li, D., ... Li, Y. (2019). Small molecule oligopeptides isolated from walnut (Juglans regia L.) and their anti-fatigue effects in mice. Molecules. https://doi.org/10.3390/molecules24010045

Lu, X., Wang, Y., \& Zhang, Z. (2009). Radioprotective activity of betalains from red beets in mice exposed to gamma irradiation. European Journal of Pharmacology. https://doi.org/10.1016/j.ejphar.2009.04.064

Lundberg, J. O., Carlstörm, M., Larsen, F. J., \& Weitzberg, E. (2011). Roles of dietary inorganic nitrate in cardiovascular health and disease. Cardiovascular Research. https://doi.org/10.1093/cvr/cvq325

Marius-Daniel, R., Stelian, S., \& Dragomir, C. (2010). The effect of acute physical exercise on the antioxidant status of the skeletal and cardiac muscle in the Wistar rat. Romanian Biotechnological Letters.

Mirmiran, P., Houshialsadat, Z., Gaeini, Z., Bahadoran, Z., \& Azizi, F. (2020). Functional properties of beetroot (Beta vulgaris) in management of cardio-metabolic diseases. Nutrition 
and Metabolism, 17(1), 1-15. https://doi.org/10.1186/s12986-019-0421-0

Moflehi, D., Kok, L. Y., Tengku-Kamalden, T. F., \& Amri, S. (2012). Effect of single-session aerobic exercise with varying intensities on lipid peroxidation and muscle-damage markers in sedentary males. Global Journal of Health Science. https://doi.org/10.5539/gjhs.v4n4p48

Nemes, R., Koltai, E., Taylor, A. W., Suzuki, K., Gyori, F., \& Radak, Z. (2018). Reactive oxygen and nitrogen species regulate key metabolic, anabolic, and catabolic pathways in skeletal muscle. Antioxidants. https://doi.org/10.3390/antiox7070085

Ninfali, P., \& Angelino, D. (2013). Nutritional and functional potential of Beta vulgaris cicla and rubra. Fitoterapia. https://doi.org/10.1016/j.fitote.2013.06.004

Pingitore, A., Lima, G. P. P., Mastorci, F., Quinones, A., Iervasi, G., \& Vassalle, C. (2015). Exercise and oxidative stress: Potential effects of antioxidant dietary strategies in sports. Nutrition. https://doi.org/10.1016/j.nut.2015.02.005

Putri, M. C., \& Tjiptaningrum, A. (2016). Efek Antianemia Buah Bit (Beta Vulgaris L.). Majority.

Sanjeev, K., Kumari, S., NK, D., \& Usha, D. (2020). Anti-Diabetic and Haematinic Effects of Beet Root Juice (Beta vulgaris L.) in Alloxan Induced Type-1 Diabetic Albino Rats. Journal of Diabetes Research and Therapy. https://doi.org/10.16966/2380-5544.150

Shiva, S., Huang, Z., Grubina, R., Sun, J., Ringwood, L. A., MacArthur, P. H., ... Gladwin, M. T. (2007). Deoxymyoglobin is a nitrite reductase that generates nitric oxide and regulates mitochondrial respiration.

Circulation

Research. https://doi.org/10.1161/01.RES.0000260171.52224.6b

Simioni, C., Zauli, G., Martelli, A. M., Vitale, M., Gonelli, A., \& Neri, L. M. (2018). Oncotarget09-17181.Pdf. Oncotarget.

Stamler, J. S., \& Meissner, G. (2001). Physiology of nitric oxide in skeletal muscle. Physiological Reviews. https://doi.org/10.1152/physrev.2001.81.1.209

Tesoriere, L., Fazzari, M., Angileri, F., Gentile, C., \& Livrea, M. A. (2008). In vitro digestion of betalainic foods. Stability and bioaccessibility of betaxanthins and betacyanins and antioxidative potential of food digesta. Journal of Agricultural and Food Chemistry. https://doi.org/10.1021/jf8017172

Thirumalai, T., Therasa, S. V., Elumalai, E. K., \& David, E. (2011). Intense and exhaustive exercise induce oxidative stress in skeletal muscle. Asian Pacific Journal of Tropical Disease. https://doi.org/10.1016/S2222-1808(11)60016-9

Winkler, C., Wirleitner, B., Schroecksn, K., Schennach, H., \& Fuchs, D. (2005). In vitro Effects of Beet Root Juice on Stimulated and Unstimulated Peripheral Blood Mononuclear Cells. American Journal of Biochemistry and Biotechnology. https://doi.org/10.3844/ajbbsp.2005.180.185

Xu, M., Liang, R., Li, Y., \& Wang, J. (2017). Anti-fatigue effects of dietary nucleotides in mice. Food and Nutrition Research. https://doi.org/10.1080/16546628.2017.1334485

Zhao, G., He, F., Wu, C., Li, P., Li, N., Deng, J., ... Peng, Y. (2018). Betaine in inflammation: Mechanistic aspects and applications. Frontiers in Immunology. https://doi.org/10.3389/fimmu.2018.01070 
